\title{
Relation between zinc status and hepatic functional reserve in patients with liver disease
}

\author{
H F Goode, J Kelleher, B E Walker
}

\begin{abstract}
Patients with liver disease may be at risk of zinc depletion. We measured polymorphonuclear cell, mononuclear cell, plasma, and erythrocyte zinc values, and erythrocyte carbonic anhydrase activity to assess zinc status in $\mathbf{1 7}$ patients with non-alcoholic liver disease (primary biliary cirrhosis and chronic active hepatitis) and 13 patients with alcoholic liver disease. The plasma zinc concentration was reduced in both patient groups and correlated strongly with the plasma albumin concentration. The mean polymorphonuclear cell zinc value in both groups was similar to that of controls but when results were combined and grouped according to hepatic functional reserve, patients with more severe liver damage (grade $\mathrm{C}$ ) had a lower polymorphonuclear cell zinc value (mean (SD) $0.86(0.24)$ $\mathrm{nmol} / \mathrm{mg}$ protein) than patients with grade $A$ $(1.44(0.43) \mathrm{nmol} / \mathrm{mg}$ protein, $\mathrm{p}<0.01)$ or grade B liver damage $(1.08(0.30) \mathrm{nmol} / \mathrm{mg}$ protein, $\mathrm{p}<0.05)$, or control subjects $(1.26(0.28) \mathrm{nmol}$ mg protein, $\mathbf{p}<0.001)$. The polymorphonuclear cell zinc value did not correlate with other indices of zinc status. The mononuclear cell zinc value was normal in all patients and was unrelated to hepatic damage. The erythrocyte zinc value and carbonic anhydrase activity were raised in alcoholic patients only. Since the polymorphonuclear cell zinc concentration is low in human experimental zinc deficiency and also correlates with tissue zinc, we suggest that our results provide evidence of progressive leucocyte zinc depletion in patients with liver disease.
\end{abstract}

Patients with liver disease may become zinc depleted through inadequate dietary intake, impaired absorption, or increased clearance of zinc. ${ }^{1-3} \mathrm{~A}$ decreased plasma zinc concentration has been reported in liver disease ${ }^{2-4}$ in conjunction with increased urinary zinc excretion, ${ }^{14}$ decreased zinc absorption, ${ }^{23}$ and decreased hepatic zinc values. ${ }^{5}$

Although in controlled experiments the plasma zinc concentration is a sensitive index of zinc depletion, in disease it is affected by many factors, particularly albumin values, and is unreliable as the sole estimate of zinc status. For this reason it has been suggested that the total leucocyte zinc value is a more reliable index. A low total leucocyte zinc value in patients with liver disease was first reported by Fredricks et $a l^{6}$ and was subsequently confirmed by other workers. ${ }^{27}$ It is unclear, however, whether previous reports of leucocyte zinc depletion in liver disease reflected the altered differential leucocyte counts frequently found in these patients, since different leucocyte subpopulations have varying zinc concentrations. ${ }^{8}$

This study was undertaken to assess whether there is evidence of zinc depletion in patients with alcoholic and non-alcoholic liver disease of varying severity by using a more extensive series of parameters to assess zinc status. We have measured the zinc content of pure populations of mononuclear and polymorphonuclear cells, plasma and erythrocytes, and activity and isoenzyme ratios of the zinc metalloenzyme, carbonic anhydrase.

\section{Subjects}

Thirty patients were studied, and informed oral consent was obtained from all. The project was approved by the local clinical research (ethics) committee.

\section{NON-ALCOHOLIC LIVER DISEASE}

Seventeen patients (14 women) aged 43-77 years were studied. Fourteen patients had primary biliary cirrhosis and three had chronic active hepatitis. Histological examination of biopsy specimens showed that all patients had cirrhosis. Patients were graded according to hepatic functional reserve, ${ }^{9}$ which takes into account the presence of ascites and encephalopathy, and biochemical indices of hepatic function (plasma albumin and bilirubin concentrations and prothrombin time). Eight patients were grade $\mathrm{A}$, six were grade $\mathrm{B}$, and three were grade $\mathrm{C}$.

\section{ALCOHOLIC LIVER DISEASE}

Thirteen patients (six women) aged $32-80$ years with alcoholic liver disease were studied. On histological examination, eight patients had cirrhosis, three had hepatitis, and two had steatosis. Four patients were grade A, two were grade $\mathrm{B}$, and seven were grade $\mathrm{C}$.

\section{CONTROLS}

Twenty three healthy medical and laboratory staff ( 11 women) aged 18-55 years were studied. None of the women were using oral contraceptives.

Blood samples were obtained from all subjects at the same time of day - between 830 and 930 am.

\section{Methods}

Stringent precautions were taken to prevent zinc contamination, as previously described in detail. ${ }^{8}$ 


\section{LEUCOCYTE ZINC}

Mononuclear and polymorphonuclear cells were separated from $10 \mathrm{ml}$ non-fasting venous blood and assayed for zinc using graphite furnace atomic absorption spectrophotometry. ${ }^{8}$

Purity of the isolated cells was assessed by non-specific esterase staining of cytocentrifuge smears and was always $>95 \%$. Viability was quantitated using trypan blue and was $>90 \% .^{8}$ Precision of the leucocyte zinc assay was $3 \cdot 8 \%$ within-batch $(n=6)$ and $9 \cdot 8 \%$ between-batch $(n=8)$. Recovery of added zinc was 99.2$100 \cdot 8 \%$. $^{8}$

\section{PLASMA AND ERYTHROCYTE ZINC}

Five millilitres of blood were centrifuged and the plasma removed. Erythrocytes were washed three times in zinc-free saline and lysed with an equal volume of zinc-free water. An aliquot of this lysate was then diluted one in 10 with water, and the remainder was used for haemoglobin and carbonic anhydrase assays. Both plasma and diluted erythrocyte lysates were further diluted one in 15 with water and aspirated directly for zinc assay by flame atomic absorption. ${ }^{10}$ Precision was $1.8 \%$ within-batch $(n=5)$ and $6.6 \%$ between-batch $(n=23)$. Commercial reference serum and an external quality assurance scheme were used to check accuracy. "

\section{ERYTHROCYTE CARBONIC ANHYDRASE}

Haemoglobin was removed from erythrocyte lysates as follows: $1 \mathrm{ml}$ of lysate was mixed for one minute with $0.2 \mathrm{ml}$ toluene, and centrifuged at $2225 \mathrm{~g}$ for 20 minutes at $4^{\circ} \mathrm{C}$. The toluene layer and membranous interface were then discarded. At $4^{\circ} \mathrm{C}, 0.2 \mathrm{ml}$ lysate was mixed for exactly one minute with $0.2 \mathrm{ml} 40 \%(\mathrm{v} / \mathrm{v})$ ethanol and $0.1 \mathrm{ml}$ chloroform, both kept at $-20^{\circ} \mathrm{C}$, and then centrifuged at $13000 \mathrm{~g}$ for five minutes.

Carbonic anhydrase esterase activity was measured in the haemoglobin-free lysates by the conversion of p-nitrophenyl-acetate to pnitrophenol. ${ }^{12}$ Precision of this assay was $6.8 \%$ $(n=10)$. The ratios of the two major isoenzymes of carbonic anhydrase (CAI and CAII) were quantitated by HPLC. ${ }^{13}$ Identification of the peaks corresponding to the isoenzymes was confirmed using commercially purified human carbonic anhydrase isoenzymes (Sigma Chemical Co Ltd, Poole).

In addition, plasma albumin and bilirubin concentrations, prothrombin time ratios, and differential leucocyte counts were measured by routine methods.

TABLE I Mean (SD) plasma, erythrocyte, and leucocyte zinc concentrations and carbonic anhydrase in patients with liver disease and control subjects

\begin{tabular}{|c|c|c|c|c|c|c|}
\hline \multirow[b]{2}{*}{ Patients } & \multirow[b]{2}{*}{$\begin{array}{l}\text { Plasma zinc } \\
\text { ( } \mu \text { molll) }\end{array}$} & \multirow{2}{*}{$\begin{array}{l}\text { Erythrocyte } \\
\text { zinc } \\
(\mu \mathrm{mol} / \mathrm{g} \mathrm{Hb})\end{array}$} & \multirow{2}{*}{$\begin{array}{l}\text { PMNC zinc } \\
\text { (nmol/mg } \\
\text { protein) }\end{array}$} & \multirow{2}{*}{$\begin{array}{l}\text { MNC zinc } \\
\text { (nmol/mg } \\
\text { protein) }\end{array}$} & \multicolumn{2}{|c|}{ Carbonic anhydrase } \\
\hline & & & & & $\begin{array}{l}\text { Activity } \\
(U / g H b)\end{array}$ & $\begin{array}{l}\text { CAI:II } \\
\text { ratio }\end{array}$ \\
\hline $\begin{array}{l}\text { Alcoholic } \\
\text { Non-alcoholic } \\
\text { Control }\end{array}$ & $\begin{array}{c}7 \cdot 5(2 \cdot 5)^{\star} \\
8 \cdot 5(2 \cdot 6)^{\star} \\
12 \cdot 7(1 \cdot 4)\end{array}$ & $\begin{array}{l}0.83(0.20)^{\star} \\
0.68(0 \cdot 14) \\
0.62(0.06)\end{array}$ & $\begin{array}{l}1.09(0.33) \\
1.17(0.44) \\
1.26(0.28)\end{array}$ & $\begin{array}{l}2 \cdot 15(0 \cdot 79) \\
2 \cdot 14(0 \cdot 47) \\
2 \cdot 00(0 \cdot 59)\end{array}$ & $\begin{array}{l}16 \cdot 6(5 \cdot 3) \dagger \\
12 \cdot 3(4 \cdot 0) \\
13 \cdot 1(2 \cdot 6)\end{array}$ & $\begin{array}{l}7 \cdot 4(2 \cdot 3) \\
7 \cdot 7(1 \cdot 1) \\
8 \cdot 6(1 \cdot 2)\end{array}$ \\
\hline
\end{tabular}

$\mathrm{PMNC}=$ polymorphonuclear MNC $=$ mononuclear

$\star$ Different from control group, $p<0 \cdot 001$; †different from control group, $p<0.02$.

\section{STATISTICAL METHODS}

Differences between data sets were compared using Student's $t$ test. Correlations were determined using the Spearman rank test. Differences were taken to be significant when $\mathrm{p}<0.05$. Results are expressed as mean (SD).

\section{Results}

The mean (SD) plasma zinc concentration was $8.56(2.61) \mu \mathrm{mol} / \mathrm{l}$ in non-alcoholic patients and $7.52(2.51) \mu \mathrm{mol} / \mathrm{l}$ in alcoholic patients, both of which were significantly lower than in control subjects $(12.69(1.40) \mu \mathrm{mol} / 1, \mathrm{p}<0.001)$, shown in Table I.

Significant correlations were found between plasma zinc and albumin values $(r=0.92$, $\mathrm{p}<0.001$ in non-alcoholic patients; $r=0.77$, $\mathrm{p}<0.01$ in alcoholics).

The mean polymorphonuclear cell zinc concentration in alcoholic patients was not low (Table I) but when these patients were subgrouped according to the degree of hepatic functional reserve, ${ }^{9}$ those with grade $\mathrm{C}$ (severe) liver damage (group $1, n=7$ ) had lower concentrations than those in whom liver damage was less severe (group 2, grades $A$ and $B, n=6$ ). The polymorphonuclear cell zinc concentration in group 1 was mean (SD) $0.88(0.19) \mathrm{nmol} / \mathrm{mg}$ protein compared with $1.53(0.47) \mathrm{nmol} / \mathrm{mg}$ protein in group $2(\mathrm{p}<0.02)$, and $1.26(0.28) \mathrm{nmol} / \mathrm{mg}$ protein in controls $(\mathrm{p}<0.02)$, shown in Figure 1 .

The same was also true of non-alcoholic patients. The group as a whole did not have a reduced mean polymorphonuclear cell zinc concentration (Table I) but when patients were subgrouped into group 1 (six grade $B$ patients and three grade $C$ patients) and group 2 (seven grade A patients), group 1 had lower polymorphonuclear cell zinc concentrations than group 2 $(0.93(0.23)$ compared with $1.36(0.40) \mathrm{nmol} / \mathrm{mg}$ protein respectively, $\mathrm{p}<0.02)$ and control subjects $(p<0.02$, Fig 1$)$. The results from both alcoholic and non-alcoholic patients were also combined and grouped according to the grading of hepatic functional reserve (Table II and Fig 1). In patients with grade $C$ hepatic functional reserve, the polymorphonuclear cell zinc concentration was $0.86(0.24) \mathrm{nmol} / \mathrm{mg}$ protein, a value that was significantly lower than that of patients with grade A $(1.44(0.43) \mathrm{nmol} /$ $\mathrm{mg}$ protein, $\mathrm{p}<0.01)$, grade $\mathrm{B}(1.08(0.30) \mathrm{nmol} /$

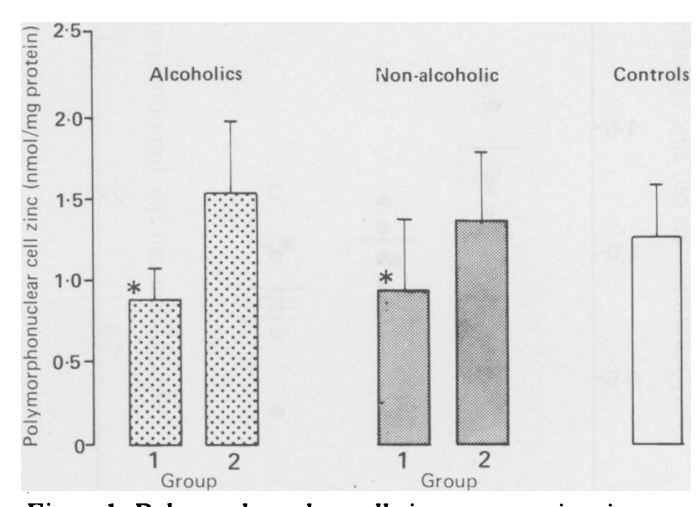

Figure 1: Polymorphonuclear cell zinc concentrations in patients with alcoholic and non-alcoholic liver disease. $\star$ Different from group 2 and controls, $p<0 \cdot 02$. 
TABLE II Mean (SD) polymorphonuclear (PMNC) and mononuclear (MNC) cell zinc concentrations in relation to hepatic function reserve grading

\begin{tabular}{lll}
\hline Grading & $\begin{array}{l}\text { PMNC zinc } \\
(\text { nmol/mg protein })\end{array}$ & $\begin{array}{l}\text { MNC zinc } \\
(\text { nmol/mg protein })\end{array}$ \\
\hline Grade A $(\mathrm{n}=12)$ & $1 \cdot 44(0 \cdot 43)$ & $2 \cdot 32(0 \cdot 46)$ \\
Grade B $(\mathrm{n}=8)$ & $1 \cdot 08(0 \cdot 30)$ & $2 \cdot 35(0 \cdot 83)$ \\
Grade C $(\mathrm{n}=10)$ & $0 \cdot 86(0 \cdot 24)^{\star}$ & $2 \cdot 00(0 \cdot 74)$ \\
Controls $(\mathrm{n}=23)$ & $1 \cdot 26(0 \cdot 28)$ & $2 \cdot 00(0 \cdot 59)$ \\
\hline
\end{tabular}

$\star$ Different from grade A ( $<<0.01)$; grade B $(p<0.05)$; and controls $(\mathrm{p}<0.001)$

mg protein, $\mathrm{p}<0.05)$, and control subjects $(1 \cdot 26$ $(0.28) \mathrm{nmol} / \mathrm{mg}$ protein, $\mathrm{p}<0.001)$

Mononuclear cell zinc concentrations were similar to control values in both patient groups (Table I), and were unrelated to the severity of hepatic damage (Table II and Fig 2).

The erythrocyte zinc value was raised in the alcoholic patients only $(0.83(0.20) \mu \mathrm{mol} / \mathrm{g} \mathrm{Hb}$ compared with $0.62(0.06) \mu \mathrm{mol} / \mathrm{g} \mathrm{Hb}$ in controls, $p<0.001$ ) and was unrelated to the severity of liver damage (Table I). The carbonic anhydrase activity was also increased in the alcoholic group (16.6 (5.3) U/g Hb compared with $13 \cdot 1(2 \cdot 6) \mathrm{U} / \mathrm{g} \mathrm{Hb}$ in controls $(\mathrm{p}<0.02$, Table I)) and correlated significantly with the erythrocyte zinc value $(\mathrm{r}=0.64, \mathrm{p}<0.05)$. Carbonic anhydrase isoenzyme ratios were normal in all patients.

\section{Discussion}

A decreased plasma zinc concentration has been widely reported in patients with liver disease ${ }^{1347}$ in conjunction with low plasma albumin values and a reduced affinity of plasma albumin for zinc. ${ }^{14}$ The present study confirmed the markedly decreased plasma zinc concentrations which correlated with plasma albumin values. The total plasma zinc value is decreased in the presence of a reduced plasma albumin value, which occurs in a wide variety of unrelated diseases, rendering the plasma zinc value alone a poor index of zinc status. ${ }^{4}$ The raised erythrocyte zinc value found in alcoholic patients in this study is in contrast mononuclear cell zinc concentrations in relation to hepatic functional reserve grading in patients with liver disease.
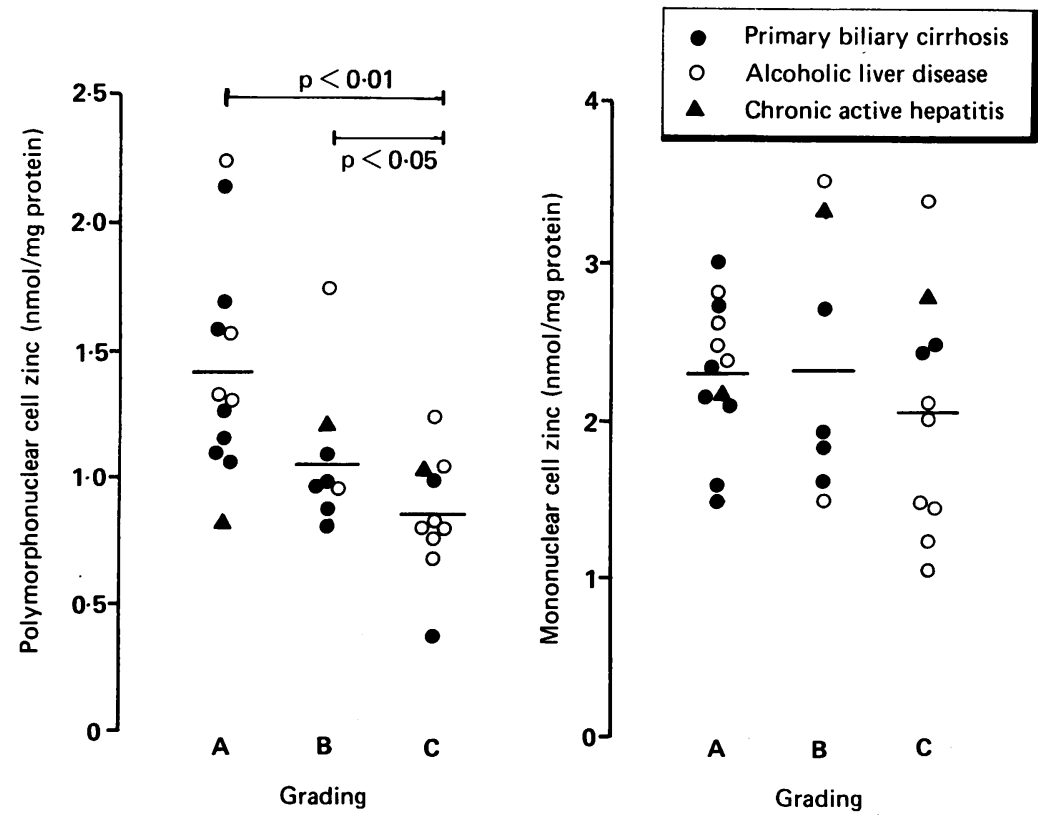

with previous studies ${ }^{67}$ where normal values were found. In patients undergoing dialysis, however, the erythrocyte zinc value inversely reflected changes in the plasma zinc concentration, ${ }^{15}$ as was found in the present study. Most of the zinc in erythrocytes is present in carbonic anhydrase, ${ }^{16}$ confirmed in this study by the correlation between carbonic anhydrase activity and erythrocyte zinc concentration. The increased erythrocyte zinc values found in our alcoholic patients may be secondary to increased carbonic anhydrase activity as part of the hypermetabolic state found in some alcoholic patients. ${ }^{17}$

Reports of low total leucocyte zinc values in patients with liver disease are somewhat conflicting. Valberg ${ }^{2}$ found that the total leucocyte zinc concentration was only low in those patients with decompensated liver disease of alcoholic aetiology and that those patients with non-alcoholic disease had normal leucocyte zinc concentrations. Keeling et al ${ }^{7}$ however, found that $19 \%$ of patients with alcoholic cirrhosis, compared with $54 \%$ of those with non-alcoholic cirrhosis, had low total leucocyte zinc concentrations that were unrelated to the patient's clinical state. Total leucocyte populations consist of a variety of cells of differing morphology, function, and halflife, ${ }^{18}$ and also of zinc content.$^{8}$ Measurement of the zinc content of pure leucocyte populations may therefore provide a better index of zinc status. Our results show that the decreased total leucocyte zinc concentration in liver disease is due to low polymorphonuclear cell zinc values, while mononuclear cell zinc concentration remains normal. This difference may not be surprising since mononuclear cells and polymorphonuclear cells have varying half-lives and different roles in vivo. In addition, different zinc-containing enzymes are present; for example, polymorphonuclear cells contain alkaline phosphatase, while mononuclear cells possess superoxide dismutase activity. Apart from its presence in enzymes, however, the exact role of zinc and its mechanism of entering and leaving cells is not known.

Polymorphonuclear cell zinc depletion was present in both alcoholic and non-alcoholic patients in our study and was directly related to the degree of hepatic damage. Valberg et $a l^{2}$ suggest that zinc absorption is impaired only in alcoholic liver disease but subsequent studies have shown that zinc absorption ${ }^{3}$ and hepatic zinc concentration ${ }^{5}$ are low in both alcoholic and non-alcoholic liver disease. Although it has been reported that the liver zinc content does not correlate with the leucocyte zinc value, ${ }^{19}$ a more recent study has shown that hepatic zinc concentrations in alcoholic patients were related to the severity of liver damage. ${ }^{5}$

Our study provides evidence of polymorphonuclear cell zinc depletion in patients with both alcoholic and non-alcoholic liver disease. We have found that polymorphonuclear cell zinc concentrations decrease in human experimental zinc depletion" and correlate strongly with abdominal muscle zinc, ${ }^{20}$ and suggest that polymorphonuclear cell zinc rather than total leucocyte zinc values may provide a better index of zinc status. The clinical and biochemical 
effects of zinc supplementation in patients with liver disease have yet, however, to be determined.

We thank the West Riding Medical Research Trust for financial support, all the patients who participated in the study and their consultants, and Mrs E Tasker for secretarial assistance.

1 McClain CJ, Su LC. Zinc deficiency in the alcoholic: a review. Alcohol Clin Exp Res 1983; 7: 5-10.

2 Valberg LS, Flanagan PR, Ghent CN, Chamberlain MJ. Zinc absorption and leucocyte zinc in alcoholic and non-alcoholic cirrhosis. Dig Dis Sci 1985; 30: 329-33.

3 Karaclyclin S, Arcasoy A, Uzunalimoglu O. Zinc plasma levels after oral zinc tolerance test in non-alcoholic cirrhosis. Dig Dis Sci 1988; 33: 1096-102.

4 Walker BE, Dawson JB, Kelleher J, Losowsky MS. Plasma and urinary zinc in patients with malabsorption syndromes and urinary zinc in patients with malabsorpt

5 Bode JC, Hanisch P, Henning H, Koenig W, Richter EW, Bode C. Hepatic zinc content in patients with various stages of alcoholic liver disease and in patients with chronic active and chronic persistent hepatitis. Hepatology 1988; 8: 1605-9.

6 Fredricks RE, Tanaka KR, Valentine WN. Zinc in human blood cells: normal values and abnormalities associated with liver disease. $\mathcal{F}$ Clin Invest 1960; 39: 1651-6.

7 Keeling PWN, Jones RB, Hilton PJ, Thompson RPH. Reduced leucocyte zinc in liver disease. Gut 1980; 21 : 561-4.

8 Goode HF, Kelleher J, Walker BE. Zinc concentrations in pure populations of peripheral blood neutrophils, lymphocytes and monocytes. Ann Clin Biochem 1989; 26: 89-95.

9 Pugh RNH, Murray-Lyon IM, Dawson JL, Pietroni MC, Williams R. Transection of the oesophagus for bleeding oesophageal varices. Brf Surg 1973; 60: 646-9.
10 Dawson JB, Walker BE. Direct determination of zinc in whole blood, plasma and urine by atomic absorption spectroscopy. Clin Chim Acta 1969; 26: 465-75.

11 Goode HF. Assessment of zinc in various blood components with relevance to body zinc status [PhD Thesis). University with relevance
of Leeds, 1989 .

12 Shapira E, Ben-Yoseph Y, Eyal FG, Russell A. Enzymatically inactive red cell carbonic anhydrase $B$ in a family with renal tubular acidosis. $\mathcal{F}$ Clin Invest 1974; 53: 59-63.

13 Hewett-Emmett D. Analytical and preparative HPLC of the three human carbonic anhydrase isoenzmes and their tryptic peptides on reverse phase columns [Abstract]. Fed Proc 1982; 41: 1385

14 Giroux E, Schechter PJ, Schoun J, Sjoerdsma A. Reduced binding of added zinc in serum of patients with decompensated hepatic cirrhosis. Eur f Clin Invest 1977; 7: 71-3.

15 Beerbower KS, Raess BU. Erthyrocyte, plasma, urine and dialysate zinc levels in patients on continuous ambulatory dialysate zinc levels in patients on continuous ambula

16 Swaminathan R, Chapman C, Segall NH, Morgan DB. Red blood cell composition in thyroid disease. Lancet 1976; ii: blood cell composition in thyroid disease. Lancet 1976; ii: $1382-5$.

17 Weiner FR, Czaja MJ, Zern MA. Ethanol and the liver. In: Arias IM, Jakoby WB, Popper H, Shachter D, Shafritz DA, eds. The liver: biology and pathobiology. New York: Raven Press, 1988: 1169 .

18 Roitt I, Brostoff J, Male D. Immunology. London: Gower Medical, 1985.

19 Jones RB, Keeling PWN, Hilton PJ, Thompson RPH. The relationship between leucocyte and muscle zinc in health and disease. Clin Sci 1981; 60: 237-9.

20 Goode HF, Kelleher J, Walker BE, Hall RI, Guillou PJ. The relationship between leucocyte and muscle zinc in surgical patients with and without gastrointestinal cancer [Abstract]. patients with and without
Proc Soc (in press). 